DOI: https://doi.org/10.24127/ajpm.v8i3.2379

\title{
ANALISIS KESALAHAN SISWA DALAM MENYELESAIKAN SOAL TES KEMAMPUAN BERPIKIR KREATIF MATEMATIS MATERI LINGKARAN
}

\author{
Hesty Marwani Siregar \\ Pendidikan Matematika, Universitas Riau \\ E-mail: hesty.marwani@lecturer.unri.ac.id
}

Received 10 October 2019; Received in revised form 8 December 2019; Accepted 28 December 2019

\begin{abstract}
Abstrak
Tujuan penelitian ini yaitu mendeskripsikan jenis kesalahan yang dilakukan siswa kelas VIII beserta penyebabnya dalam menyelesaikan soal materi lingkaran berdasarkan kemampuan berpikir kreatif matematis. Penelitian ini merupakan penelitian kualitatif. Pengumpulan data penelitian menggunakan tes kemampuan berpikir kreatif matematis materi keliling dan luas lingkaran serta pertanyaan terbuka terkait pandangan siswa mengenai soal berpikir kreatif matematis. Hasil penelitian yang diperoleh adalah: 1) jenis kesalahan dalam menyelesaikan soal berpikir kreatif matematis materi lingkaran yaitu kesalahan mengenai konsep unsur-unsur lingkaran, salah dalam menentukan yang diketahui dari soal, sulit menyelesaikan soal dengan lebih dari satu cara, kesalahan dalam perhitungan, dan salah dalam menentukan rumus; 2) penyebab siswa melakukan kesalahan dalam menyelesaikan soal berpikir kreatif matematis materi lingkaran yaitu kurang memahami dan tidak mengingat materi lingkaran, siswa belum paham konsep dasar pada materi sebelumnya, siswa tidak paham maksud soal, siswa kesulitan melihat kaitan antar materi pada matematika serta menghubungkannya.
\end{abstract}

Kata kunci: Kemampuan berpikir kreatif matematis; penyebab kesalahan; jenis kesalahan.

\begin{abstract}
This research aims to describe various kinds and factors causing of student mistakes in solving the problem of the circle in eight grade based on mathematical creative thinking abilities. This research was qualitative research. Data collection methods used were the test of mathematical creative thinking abilities of circumference and area of the circle, and interview about students' views on mathematical creative thinking problems. The result of this study are: 1) various kind of student's mistake i.e. errors regarding the concept of circle, errors in getting information from the problem, can not find the multiple problem solving, errors in calculations, and use the wrong formula; 2) the cause of students making mistakes in solving the problem of circle based on mathematical creative thinking abilities i.e. lack of understanding and not remembering circle matter, did not understand prerequisite matter, did not understand the problem, can not find the relationships between mathematical concept.
\end{abstract}

Keywords: Mathematical creative thinking abilities; the cause of mistake; type of mistake.

\section{PENDAHULUAN}

Perkembangan ilmu pengetahuan dan teknologi menuntut manusia untuk terus meningkatkan keterampilan dan pengetahuan yang dimilikinya. Pengetahuan yang dapat diakses darimana saja mengakibatkan perlunya kemampuan memperoleh, memilih dan mengolah informasi. Kemampuankemampuan tersebut membutuhkan pemikiran yang sistematis, logis, kritis, dan kreatif. Oleh karena itu diperlukan suatu pembelajaran yang dapat mengembangkan kemampuan berpikir kritis, sistematis, logis, dan kreatif. Salah satu pengajaran yang dapat mengembangkan kemampuan tersebut dapat dilakukan melalui pembelajaran matematika.

Matematika memiliki andil dalam memberikan berbagai macam kemampuan dan sikap yang diperlukan 
oleh manusia agar bisa hidup cerdas dalam lingkungannya. Hasratuddin (2014) mengemukakan kemampuankemampuan yang dapat diperoleh dari matematika antara lain; 1) kemampuan berhitung, 2) kemampuan spasial, 3) kemampuan melakukan berbagai macam pengukuran, 4) kemampuan mengamati, mengorganisasi, mendeskripsi, menyajikan, dan menganalisis data, 5) kemampuan melakukan kuantifikasi terhadap berbagai variabel dalam berbagai bidang kehidupan, 6) kemampuan mengamati pola atau struktur dari suatu situasi, 7) kemampuan untuk membedakan hal-hal yang relevan dan hal-hal yang tidak relevan pada suatu masalah, 8) kemampuan membuat prediksi berdasarkan data-data yang ada, 9) kemampuan menalar secara logis, 10) kemampuan berpikir dan bertindak secara konsisten, 11) kemampuan berpikir dan bertindak secara mandiri berdasarkan alasan yang dapat dipertanggungjawabkan, 12) kemampuan berpikir kreatif dan memecahkan masalah dalam berbagai situasi.

Salah satu kemampuan matematika yang perlu dimiliki siswa adalah kemampuan berpikir kreatif matematis. Namun, berdasarkan penelitian, kemampuan berpikir kreatif matematis siwa kelas VII SMP Negeri 9 Kendari pada materi bangun datar masih rendah (Safaria \& Sangila, 2018).

Peningkatan kemampuan berpikir kreatif matematis dapat dilakukan melalui pembelajaran matematika. Sayangnya, dalam praktek pembelajarannya, siswa masih menganggap matematika sebagai mata pelajaran yang sulit (Sholihah \& Afriansyah, 2017). Pernyataan tersebut sejalan dengan pendapat Pradana (2016) bahwa matematika merupakan salah satu pelajaran yang masih dianggap sulit dipahami oleh siswa. Hal serupa dikemukakan oleh Mutia (2017), siswa merasa pelajaran matematika sulit khususnya dalam pemahaman konsep. Sementara Utami (2017) menyatakan bahwa siswa masih memandang matematika sebagai pelajaran yang menakutkan, karena siswa sulit memahami materi yang kajiannya abstrak pada matematika.

Terkait kesulitan belajar, menurut National Joint Committee on Learning Disabilities (NJCLD), kesulitan belajar adalah sekelompok kesulitan dalam hal memperoleh maupun menggunakan keterampilan mendengarkan, berbicara, membaca, menalar, atau dalam matematika (Fatoni \& Ainin, 2019).

Sedangkan penyebab kesulitan belajar yang dikemukakan Nursalam (2016) yaitu: 1) siswa tidak mengetahui apa yang dipelajari dan cara mencapai hasil yang diharapkan, 2) tidak memiliki motivasi belajar, 3) menganggap belajar sama dengan menghafal, 4) tidak konsentrasi saat belajar, 5) belajar dilakukan sewaktu ada ujian saja, 6) bersikap pasif dalam pelajaran di sekolah, 7) membaca tanpa memahami isi bacaan.

Penerapan metode pembelajaran ini akan berdampak lebih baik bagi kemampuan berpikir kreatif matematis jika pembelajaran dapat ditekankan pada aspek berpikir kreatif yang dirasa masih kurang. Untuk itu, peneliti maupun guru perlu melakukan penyelidikan mengenai kesalahan jawaban siswa pada aspek berpikir kreatif. Dengan melakukan penyelidikan ini, peneliti maupun guru dapat memperoleh gambaran mengenai kelemahan siswa pada kemampuan berpikir kreatif yang perlu mendapat perhatian. Hal ini sesuai dengan pernyataan Dewi (2014) yang 
menyatakan bahwa kesalahan atau kesulitan yang dialami siswa dapat ditelusuri sehingga dapat dilakukan tindakan pencegahan ataupun penanggulangan pada pembelajaran. Penyelidikan mengenai kesalahan jawaban siswa terkait suatu materi pelajaran disebut analisis kesalahan (Solfitri, Siregar, \& Syari, 2019).

Analisis kesalahan terkait kemampuan berpikir kreatif matematis sudah dilakukan pada materi persamaan garis lurus (Putra, Akhdiyat, Setiany, Andiarani, 2018). Pada penelitian tersebut, diperoleh hasil sebanyak $18,18 \%$ siswa sudah kreatif dalam menyelesaikan soal, $66,66 \%$ siswa tergolong cukup kreatif, dan 15,15\% siswa masih kurang kreatif. Kesulitan yang dialami siswa yang menjadi subjek penelitian antara lain tidak dapat memahami makna dari grafik soal yang diberikan dan kurang memahami cara menentukan persamaan garis dari konsep gradien. Pada penelitian ini, dari hasil analisis jawaban, siswa digolongkan ke dalam kategori kreatif, cukup kreatif, dan kurang kreatif. Pada penelitian ini belum dilakukan analisis jawaban siswa pada indikator berpikir kreatif.

Analisis kesalahan kemampuan berpikir kreatif matematis juga telah dilakukan pada materi trigonometri (Suparman dan Zanthy, 2019). Penelitian ini memperoleh hasil bahwa kesalahan siswa dalam menyelesaikan soal berpikir kreatif terjadi pada pembuatan model matematika, indentifikasi ketercukupan unsur dan konsep yang termuat, serta keliru dalam operasi hitung. Namun, analisis kesalahan pada penelitian ini dilakukan pada dua indikator terendah saja, yaitu berpikir lentur dan berpikir orisinil.

Penelitian terdahulu memiliki kesamaan dengan penelitian ini, yaitu menganalisis kesalahan yang dilakukan siswa SMP pada tes kemampuan berpikir kreatif matematis. Perbedaan penelitian yang dilakukan dengan penelitian terdahulu yaitu dari segi materi dan aspek berpikir kreatif matematis yang dianalisis. Materi tes berpikir kreatif matematis adalah Keliling dan Luas Lingkaran, sedangkan aspek berpikir kreatif matematis yang digunakan yaitu kelancaran, penguraian, keluwesan, dan keaslian. Berdasarkan uraian tersebut, maka tujuan penelitian ini untuk menganalisis kesalahan yang dilakukan siswa SMP pada materi keliling dan luas lingkaran ditinjau dari aspek kemampuan berpikir kreatif matematis.

\section{METODE PENELITIAN}

Penelitian ini menggunakan rancangan penelitian kualitatif dengan pendekatan deskriptif. Hal yang dideskripsikan dalam penelitian ini adalah kesalahan siswa dalam menyelesaikan soal lingkaran berdasarkan kemampuan berpikir kreatif matematis.

Pada penelitian kualitatif menggunakan Purposive sampling adalah teknik pengambilan sampel berdasarkan alasan tertentu. Subjek penelitian ini adalah 35 orang siswa kelas VIII di salah satu SMP Negeri Pekanbaru.

Langkah-langkah analisis kesalahan yaitu: 1) mengumpulkan data kesalahan siswa dalam menyelesaikan soal, 2) mengidentifikasi dan mengklasifikasi kesalahan, 3) menjelaskan kesalahan, 5) memperkirakan soal yang rawan terjadi kesalahan, 6) mengoreksi kesalahan.

Pengumpulan data dilakukan dengan menggunakan instrumen tes kemampuan berpikir kreatif matematis materi keliling dan luas lingkaran serta pertanyaan terbuka terkait pandangan 
siswa mengenai soal berpikir kreatif matematis, yang digunakan untuk mengetahui letak kesalahan siswa dalam menyelesaikan soal. Langkah-langkah yang dilakukan dalam penulisan soal yaitu: 1) membuat kisi-kisi soal, 2) membuat butir soal, 3) membuat kunci jawaban soal, 4) validasi tes. Soal tes kemampuan berpikir kreatif matematis divalidasi oleh 2 dosen pendidikan matematika dan 1 orang guru matematika. Adapun soal tes berjumlah 7 soal yang memuat indikator kemampuan berpikir kreatif matematis kelancaran, penguraian, keluwesan, dan keaslian.

Analisis data dilakukan pada saat dan setelah pengumpulan data. Prosedur analisis dan penafsiran data dilakukan sesuai langkah berikut.

1. Memberikan lalu memeriksa hasil tes dengan skor maksimum masingmasing butir soal adalah 4 .

2. Menghitung rata-rata dan persentase ketercapaian setiap butir soal. Rumus rata-rata dan rumus persentase yang digunakan adalah sebagai berikut.

$$
\text { rata }- \text { rata }=\frac{\text { jumlah skor seluruh siswa }}{\text { banyak siswa }}
$$

(Rumus 1)

$$
\text { persentase }=\frac{\text { rata }- \text { rata }}{\text { skor } \text { maksimal }} \times 100 \%
$$

(Rumus 2)

Dengan mengetahui rata-rata dan persentase ketercapaian setiap butir soal, maka dapat diketahui indikator berpikir kreatif mana yang masih lemah.

3. Menganalisis hasil tes berdasarkan indikator kemampuan berpikir kreatif matematis.

4. Menentukan jenis kesalahan yang dilakukan siswa di setiap indikator.

5. Menarik kesimpulan berdasarkan analisis jawaban tes kemampuan berpikir kreatif matematis.

\section{HASIL PENELITIAN DAN PEMBAHASAN}

Instrumen tes kemampuan berpikir kreatif matematis terdiri dari 7 soal yang dikembangkan berdasarkan indikator kemampuan berpikir kreatif matematis yang digunakan dalam penelitian yaitu kelancaran, penguraian, keluwesan, dan keaslian. Indikator berpikir kreatif soal nomor 1 dan 4 yaitu kelancaran terkait dengan menjawab masalah matematika dengan jawaban yang relevan dan arus pemikiran lancar. Indikator berpikir kreatif soal nomor 2 dan 3 adalah penguraian terkait dengan memberikan jawaban secara terperinci. Sementara indikator berpikir kreatif pada soal nomor 5 adalah keluwesan terkait dengan menggunakan beberapa cara dalam menyelesaikan masalah. Untuk indikator berpikir kreatif nomor 6 dan 7 adalah keaslian terkait dengan menjawab masalah matematika dengan menggunakan bahasa, cara, atau idenya sendiri. Rataan skor tes kemampuan berpikir kreatif matematis untuk masing-masing indikator disajikan pada Tabel 1 .

Tabel 1. Deskripsi rataan skor tes kemampuan berpikir kreatif matematis berdasarkan indikator

\begin{tabular}{llll}
\hline No & Indikator & $\begin{array}{c}\text { Rata- } \\
\text { Rata }\end{array}$ & $\begin{array}{c}\text { Persentase } \\
(\%)\end{array}$ \\
\hline 1 & Kelancaran & 3,29 & 82,25 \\
2 & Penguraian & 2,97 & 74,25 \\
3 & Penguraian & 2 & 50 \\
4 & Kelancaran & 0,91 & 22,75 \\
5 & Keluwesan & 0,86 & 21,5 \\
6 & Keaslian & 2,31 & 57,75 \\
7 & Keaslian & 1,31 & 32,75 \\
\hline
\end{tabular}

Berdasarkan Tabel 1 terlihat bahwa pencapaian siswa untuk indikator kelancaran nomor 4, keluwesan dan keaslian nomor 7 belum mencapai $50 \%$. Pada soal keluwesan, siswa diminta 
untuk menentukan luas daerah yang diarsir dengan lebih dari satu cara. Dari jawaban yang diberikan, siswa kesulitan untuk menjawab soal tersebut dengan lebih dari satu cara. Sebagian siswa hanya mampu menjawab soal tersebut dengan satu cara. Pada soal nomor 4, siswa diminta untuk menuliskan semua kemungkinan banyak taplak meja yang dapat dibuat. Dari jawaban yang diberikan, siswa kesulitan menentukan rumus yang tepat untuk menyelesaikan soal tersebut. Akibatnya siswa tidak dapat membuat kombinasi banyak taplak meja yang bisa dibuat. Sementara untuk indikator keaslian pada soal nomor 7, siswa diminta untuk menjawab soal dengan cara yang berbeda dari cara yang disajikan pada soal. Sebagian siswa kesulitan menemukan cara lain untuk menjawab soal tersebut, sehingga siswa memberikan jawaban yang tidak selesai. Untuk melihat contoh jawaban siswa masing-masing indikator dapat dilihat pada uraian berikut.

1. Perhatikan gambar roda sepeda di bawah ini.

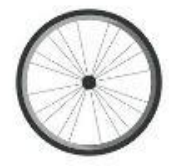

Gambar ulang roda tersebut dilengkapi dengan keterangan unsur-unsur lingkaran yang terdapat pada roda! Beri penjelasan mengenai unsur-unsur lingkaran yang terdapat pada gambar roda tersebut!

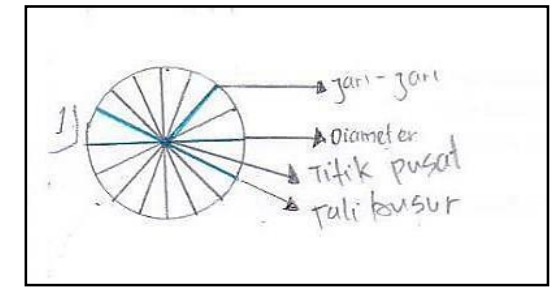

Gambar 1. Salah satu jawaban siswa pada butir soal no. 1
Gambar 1 merupakan salah satu jawaban siswa, dimana siswa menjawab pertanyaan tanpa disertai penjelasan seperti yang diminta soal. Siswa tersebut telah menggambar kembali roda dan melengkapi gambar tersebut dengan unsur-unsur lingkaran, tetapi belum memberi penjelasan mengenai unsur-unsur lingkaran tersebut. Hal ini dikarenakan siswa tidak dapat mengingat konsep unsur-unsur lingkaran secara lengkap.

2. Gambar di bawah ini merupakan model persegi panjang berukuran $60 \mathrm{~cm} \times 40 \mathrm{~cm}$, yang memuat 6 buah persegi yang kongruen dan 6 buah lingkaran yang kongruen. Bagaimana langkah yang akan kamu gunakan untuk menentukan luas daerah yang diarsir? Dengan menggunakan langkah tersebut, tentukan luas daerah yang diarsir! $(\pi=3,14)$.

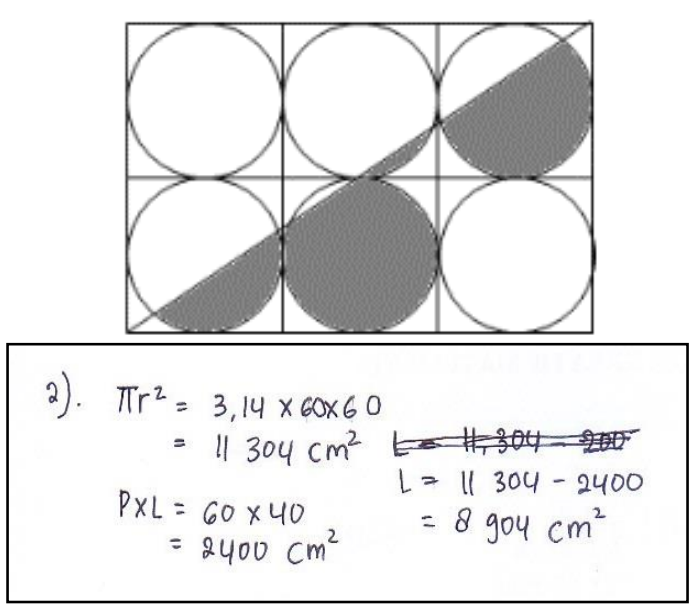

Gambar 2. Salah satu jawaban siswa pada butir soal no. 2

Gambar 2 merupakan salah satu jawaban siswa yang belum mampu menyelesaikan persoalan dengan benar. Siswa tersebut menganggap ukuran jarijari lingkaran pada gambar adalah 60 $\mathrm{cm}$. Selain itu, siswa juga menentukan luas daerah yang diarsir dengan mengurangkan luas persegi panjang 
berukuran $60 \mathrm{~cm}$ x $40 \mathrm{~cm}$ dengan luas lingkaran berjari-jari $60 \mathrm{~cm}$. Seharusnya siswa terlebih dahulu menentukan jarijari 1 lingkaran melalui membagi $60 \mathrm{~cm}$ dengan 6 atau membagi $40 \mathrm{~cm}$ dengan 4. Selanjutnya daerah yang diarsir, jika digabungkan akan menjadi 2 buah lingkaran berjari-jari $10 \mathrm{~cm}$, sehingga untuk menentukan luas daerah yang diarsir dapat dilakukan dengan menentukan dua kali luas daerah lingkaran berjari-jari $10 \mathrm{~cm}$. Hal ini disebabkan siswa tidak dapat menghubungkan unsur-unsur yang diketahui dari soal, selain itu siswa juga tidak paham rumus yang paling tepat untuk digunakan dalam menyelesaikan soal.

3. Anto bermain bersama temantemannya dengan melompat sambil bernyanyi mengelilingi lingkaran berdiameter $3,5 \mathrm{~m}$, dan terdapat 10 titik bernomor $1,2,3, \ldots, 10$ seperti pada gambar di bawah ini.

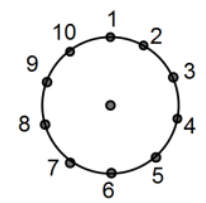

Dalam permainan ini, pemain berdiri di salah satu nomor, kemudian melompat searah jarum jam ke nomor lainnya setelah mendengar aba-aba. Jika seorang anak berada pada nomor yang merupakan bilangan prima, maka dia melompat ke satu nomor berikutnya. Selanjutnya, jika anak tersebut berada pada nomor yang bukan bilangan prima, maka dia melompat ke tiga nomor berikutnya. Misalkan mula-mula Anto berada pada posisi nomor 1 , bagaimana cara menentukan jarak yang ditempuh Anto setelah perpindahan ke 17 ?
Berdasarkan cara tersebut, tentukan jarak yang ditempuh Anto!

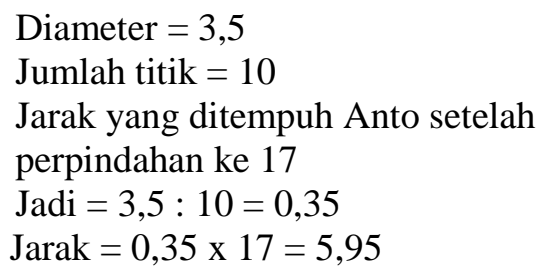

Gambar 3. Salah satu jawaban siswa pada butir soal no.3

Gambar 3 merupakan salah satu jawaban siswa yang menunjukkan bahwa siswa belum mampu menyelesaikan persoalan dengan benar. Untuk menentukan jarak yang ditempuh Anto setelah perpindahan ke-17, siswa tersebut membagi diameter dengan banyak nomor di lingkaran, kemudian mengalikan hasilnya dengan 17. Seharusnya siswa tersebut terlebih dahulu menentukan keliling lingkaran. Selanjutnya menentukan posisi Anto berdasarkan peraturan permainan setelah perpindahan ke-17. Berikutnya menentukan berapa kali keliling lingkaran yang telah dilalui Anto sampai perpindahan ke-17. Untuk menentukan jarak yang ditempuh Anto setelah perpindahan ke-17, siswa mengalikan keliling lingkaran dengan berapa kali keliling lingkaran yang telah dilalui Anto. Kesalahan yang terjadi pada soal nomor 3 disebabkan siswa tidak dapat menghubungkan unsurunsur yang diketahui dari soal dan tidak memahami konsep keliling lingkaran.

4. Ita bekerja di pabrik sebagai pembuat batik untuk taplak meja. Taplak meja yang menjadi tugasnya seharihari adalah taplak meja yang berbentuk lingkaran. Berdasarkan jenis produk, ukuran kain yang menjadi tugas Ita, yaitu tipe A dengan diameter $28 \mathrm{~cm}$, tipe $\mathrm{B}$ 
dengan diameter $56 \mathrm{~cm}$, dan tipe $\mathrm{C}$ dengan diameter $84 \mathrm{~cm}$. Dalam 1 jam, Ita bisa menyelesaikan motif batik dengan luas $0,2 \mathrm{~m}^{2}$, serta dalam sehari Ita bekerja 8 jam di pabrik tersebut. Apabila setiap hari Ita harus dapat menyelesaikan motif batik minimal 1 taplak meja per produk. tentukan semua kemungkinan jumlah maksimal masing-masing tipe produk yang dapat dibuat Ita dalam 1 hari. Beri penjelasan mengenai jawabanmu!

Dik: tipe $A=28 \mathrm{~cm}$

Tipe $\mathrm{B}=56 \mathrm{~cm}$

Tipe $\mathrm{C}=84 \mathrm{~cm}$

1 jam Ita menyelesaikan motif batik

$0,2 \mathrm{~m}^{2}$

$0,2 \mathrm{~m}^{2}=20 \mathrm{~cm}$

Dit : tentukan kemungkinan berapa jumlah maksimal yang bisa dibuat Ita dalam sehari?

Jwb:

Tipe $\mathrm{A}=28 \mathrm{~cm}=20 \mathrm{~cm} \times 8=160 \mathrm{~cm}$

Tipe $A=\frac{160}{28}=5,6$ kain

Tipe $\mathrm{B}=56 \mathrm{~cm}=20 \mathrm{~cm} \times 8=\frac{160 \mathrm{~cm}}{56 \mathrm{~cm}}=2,4$ kain

Tipe $\mathrm{C}=84 \mathrm{~cm}=20 \times 8=\frac{160}{84}=0,2$ kain

Gambar 4. Salah satu jawaban siswa pada butir soal no. 4

Gambar 4 merupakan salah satu jawaban siswa yang menyelesaikan soal dengan cara membagi luas kain yang dapat dikerjakan Ita dalam satu hari dengan diameter taplak meja. Seharusnya siswa terlebih dahulu menentukan luas taplak meja untuk masing-masing tipe, kemudian menentukan luas kain yang dapat diselesaikan Ita dalam sehari. Selanjutnya untuk menjawab permasalahan, siswa membuat kombinasi banyak masing-masing taplak meja yang bisa dibuat Ita dalam satu hari. Kesalahan yang terjadi pada soal nomor 3 disebabkan siswa tidak memahami konsep luas lingkaran, tidak paham soal, sehingga tidak dapat memilih rumus yang tepat untuk menyelesaikan soal.

5. Di sepetak tanah berbentuk persegi akan dibuat taman bunga dengan rencana seperti pada gambar di bawah ini.

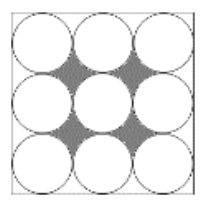

Kesembilan lingkaran tersebut kongruen, dan keliling lingkaran adalah $6,28 \mathrm{~m}$ dengan $\pi=3,14$. Pada daerah yang berbentuk lingkaran akan ditanam bunga, sementara pada daerah yang diarsir akan ditanami rumput. Tentukan luas tanah yang akan ditanami rumput dengan lebih dari satu cara! Jelaskan cara yang kamu gunakan!

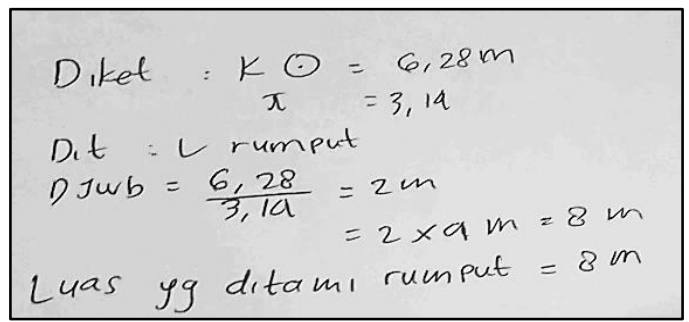

Gambar 5. Salah satu jawaban siswa pada butir soal no. 5

Gambar 5 merupakan salah satu jawaban siswa yang menunjukkan bahwa siswa belum mampu menyelesaikan persoalan dengan benar. Siswa sudah memperoleh nilai d, tetapi siswa tersebut menganggap luas yang diarsir sama dengan empat kali diameter. Padahal, luas yang diarsir sama dengan luas persegi dengan panjang sisi $2 m$ dikurang luas lingkaran 
berjari-jari $1 m$, yang hasilnya dikalikan dengan empat. Kesalahan yang terjadi pada soal nomor 3 disebabkan siswa tidak memahami konsep luas lingkaran dan luas persegi serta tidak mampu menghubungkan konsep-konsep tersebut, sehingga siswa tidak dapat menentukan rumus yang tepat untuk menyelesaikan soal. Selain itu, siswa juga tidak dapat menemukan cara lain untuk menjawab soal tersebut.

6. Suatu bidang berbentuk seperti gambar berikut ini.

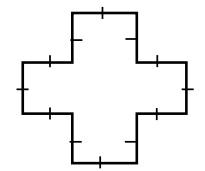

Tetapkan ukuran dalam satuan $\mathrm{cm}$ untuk bidang tersebut, yang menurut kamu tepat. Gambar ulang bidang tersebut berdasarkan ukuran yang kamu tetapkan, kemudian susun lingkaran dengan diameter $1 \mathrm{~cm}$ di dalam bidang tersebut. Berapa jumlah maksimum lingkaran yang dapat dimuat dalam bidang yang kamu buat? Bagaimana cara kamu menentukan luas daerah di luar lingkaran-lingkaran yang berada pada bidang tersebut? Tentukan luas daerah tersebut berdasarkan cara yang kamu gunakan!

Gambar 6 merupakan salah satu jawaban siswa yang menunjukkan bahwa masih terdapat kekeliruan pada jawaban siswa. Siswa sudah menetapkan ukuran untuk bidang tersebut dan memperoleh jumlah lingkaran maksimum yang dapat termuat di dalam bidang. Namun ketika menentukan luas daerah di luar lingkaran-lingkaran yang berada pada bidang, siswa tidak mengalikan luas lingkaran dengan jumlah lingkaran yang ada, sehingga diperoleh hasil yang kurang tepat. Seharusnya untuk menentukan luas daerah di luar lingkaran-lingkaran yang berada pada bidang, siswa mengurangkan lima kali luas daerah persegi dengan dua puluh kali luas daerah lingkaran. Penggunaan rumus yang kurang tepat ini disebabkan siswa kurang teliti dalam mengerjakan soal.

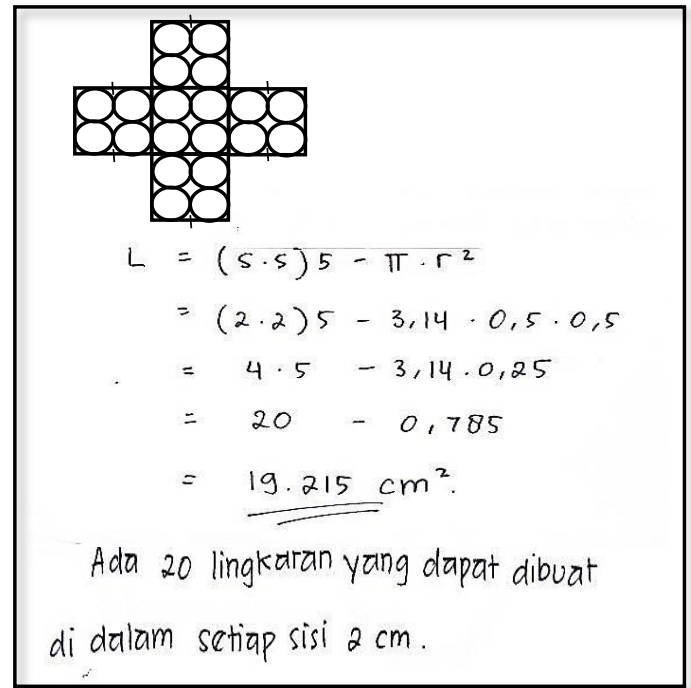

Gambar 6. Salah satu jawaban siswa pada butir soal no.6

7.

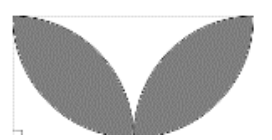

Lengkungan pada gambar di atas merupakan busur lingkaran yang berjari-jari sama. Untuk menentukan luas daerah yang diarsir, Fika menggunakan langkah-langkah berikut.

a. Menentukan luas persegi panjang dan luas seperempat lingkaran

b. Mengurangkan luas persegi panjang dengan dua kali luas seperempat lingkaran

c. Luas daerah yang diarsir diperoleh dengan mengurangkan luas dua kali seperempat lingkaran dengan hasil yang diperoleh pada langkah $b$. 
Tetapkan panjang jari-jari busur lingkaran pada gambar yang menurut kamu tepat. Bagaimana cara menentukan luas daerah yang diarsir menggunakan cara yang berbeda dengan Fika? Tentukan luas daerah tersebut berdasarkan cara yang kamu gunakan!

$$
\begin{aligned}
p \times l & =2 \times 4=8 \\
8-4 & =4 \\
4 \times 4 & =16-4 \\
& =12
\end{aligned}
$$

Gambar 7. Salah satu jawaban siswa pada butir soal no.7

Gambar 7 merupakan salah satu jawaban siswa yang menujukkan bahwa siswa belum mampu menyelesaikan persoalan dengan benar. Siswa sudah memperoleh luas persegi panjang, tetapi untuk menentukan luas yang diarsir, siswa mengurangkan dan mengalikan luas persegi panjang tersebut dengan 4 . Seharusnya, setelah memperoleh luas daerah persegi panjang, siswa menentukan luas daerah lingkaran. Luas daerah yang diarsir diperoleh dari hasil pengurangan luas daerah lingkaran dengan luas daerah persegi panjang. Penggunaan rumus yang kurang tepat ini disebabkan siswa belum memahami soal, tidak mengetahui hubungan antara persegi panjang dengan busur lingkaran yang terdapat pada gambar soal, dan tidak dapat menentukan penggunaan rumus yang tepat untuk menyelesaikan soal.

Kesalahan siswa dalam menjawab soal berpikir kreatif, pada umumnya terletak pada ketidakpahaman mereka tentang konsep keliling dan luas lingkaran, serta ketidakmampuan untuk menghubungkannya dengan materi matematika lain yang telah mereka pelajari. Dari jawaban siswa mengenai pandangan mereka terkait soal berpikir kreatif matematis, siswa merasa soal berpikir kreatif sangat berbeda dengan soal yang mereka biasa mereka kerjakan. Para siswa juga mengakui bahwa mereka tidak terlalu menyukai soal-soal cerita, karena sulitnya memahami soal. Selain itu, siswa selama ini merasa bahwa materi matematika tidak berhubungan dan sulit diterapkan dalam kehidupan mereka sehari-hari.

Hasil penelitian ini selaras dengan hasil penelitian Safaria \& Sangila (2018), yaitu pencapaian kemampuan berpikir kreatif matematis untuk indikator keluwesan dan keaslian juga tidak mencapai 50\%. Safaria \& Sangila (2018) berpendapat hal ini disebabkan karena siswa terbiasa mengerjakan soal yang rutin dan sederhana serta menggunakan satu rumus atau satu penyelesaian saja, sehingga ketika dihadapkan pada soal tidak rutin, mereka kesulitan ketika mengaitkan konsep-konsep matematika yang sudah dipelajari dalam menyelesaikan soal.

Berdasarkan hasil penelitian ini, kesalahan yang dilakukan siswa dalam menjawab soal berpikir kreatif matematis disebabkan siswa tidak memahami konsep lingkaran dan kaitan antar konsep di matematika. Oleh karena itu, untuk meningkatkan kemampuan berpikir kreatif matematis pada materi keliling dan luas lingkaran, guru terlebih dahulu harus memastikan bahwa siswa sudah memahami konsep keliling dan luas lingkaran dengan benar. Untuk memudahkan siswa memahami materi, guru dapat merancang pembelajaran yang menyenangkan agar materi dapat terserap dengan mudah serta mengaitkan materi matematika dengan kehidupan sehari-hari siswa. Hal ini 
sejalan dengan kajian mengenai peningkatan apresiasi siswa terhadap matematika, bahwa guru sebaiknya menggunakan metode pembelajaran yang bervariasi sesuai tujuan pembelajaran dan menggunakan masalah kontekstual sesuai materi pelajaran (Utami, 2011).

Penelitian ini juga menunjukkan bahwa siswa tidak terbiasa mengerjakan soal-soal non rutin. Untuk mengatasi hal ini, guru sebaiknya memberikan soal-soal non rutin kepada siswa, soal open-ended, dan membiasakan siswa untuk mencari alternatif pemecahan masalah selain yang telah diberikan guru dalam kegiatan pembelajaran. Hal ini sesuai dengan pernyataan bahwa siswa harus banyak dilatih menyelesaikan soal-soal non rutin yang memfasilitasi siswa untuk mampu menganalisis soal (Lisa, 2017).

Implikasi praktis penelitian ini terhadap sekolah yaitu sekolah perlu memfasilitasi guru untuk meningkatkan kompetensinya baik dalam merancang pembelajaran ataupun dalam membuat soal-soal non rutin, seperti dengan memberikan pelatihan maupun menyediakan sarana dan prasarana yang menunjang kelancaran pembelajaran.

\section{KESIMPULAN DAN SARAN}

Berdasarkan hasil penelitian serta mengacu pada tujuan penelitian maka dapat diambil simpulan sebagai berikut: 1) jenis-jenis kesalahan yang dihadapi siswa dalam menyelesaikan soal materi lingkaran adalah kesalahan mengenai konsep unsur-unsur lingkaran, salah dalam menentukan yang diketahui dari soal, sulit menyelesaikan soal dengan lebih dari satu cara, kesalahan dalam perhitungan, dan salah dalam menentukan rumus; 2) penyebab kesalahan dalam menyelesaikan soal materi lingkaran adalah siswa kurang memahami dan tidak mengingat materi lingkaran, siswa belum paham konsep dasar pada materi sebelumnya, siswa tidak paham maksud soal, siswa kesulitan melihat kaitan antar materi pada matematika serta menghubungkannya.

Saran dari hasil penelitian ini yaitu: 1) guru memberikan pembelajaran yang inovatif dan menyenangkan agar siswa tertarik untuk mempelajari matematika; 2) guru memberikan soal latihan untuk memperkuat konsep-konsep yang sudah dipelajari; 3) guru meminta siswa untuk memperhatikan dan menanyakan hal yang belum dimengerti saat proses pembelajaran; 4) pihak sekolah dapat berperan aktif dengan memfasilitasi lingkungan sekolah agar kondusif dan memiliki sarana prasarana yang memadai dalam pembelajaran di sekolah; 5) perlu adanya penelitian lanjutan mengenai pembelajaran yang dapat meningkatkan pemahaman siswa terkait materi pelajaran, mengajak siswa untuk mengerjakan soal non rutin, mendorong siswa untuk dapat menyelesaikan soal dengan lebih dari satu cara, sehingga dapat menunjang peningkatan kemampuan berpikir kreatif matematis siswa.

\section{DAFTAR PUSTAKA}

Dewi, S. I. K. (2014). Analisis Kesalahan Siswa Kelas Viii Dalam Menyelesaikan Soal Pada Materi Faktorisasi Bentuk Aljabar Smp Negeri 1 Kamal Semester Gasal Tahun Ajaran 2013/2014. MATHEdunesa Jurnal Ilmiah Pendidikan Matematika, 3(2), 195-202.

Fatoni, A., \& Ainin, I. K. (2019). Identifikasi Siswa Disleksia Di Sekolah Dasar Negeri Inklusi Surabaya Timur. Jurnal Pendidikan Khusus, 12(3), 1-11. 
Hasratuddin. (2014). Pembelajaran Matematika Sekarang dan yang akan Datang Berbasis Karakter. Didaktik Matematika, 1(2), 30-42. https://doi.org/10.24815/jdm.v1i2. 2059

Lisa. (2017). Interpretasi Dan Analisis Hasil Jawaban Kemampuan Pemecahan Masalah Matematik Siswa Kelas VII SMP Negeri 6 Lhokseumawe Pada Materi Bangun Datar. Jurnal Sarwah, 1(1).

Mutia. (2017). Analisis Kesulitan Siswa SMP dalam Memahami Konsep Kubus Balok dan Alternatif Pemecahannya. Beta Jurnal Tadris Matematika, 10(1), 83-102. https://doi.org/10.20414/betajtm.v1 $0 \mathrm{i} 1.107$

Nursalam. (2016). Diagnostik Kesulitan Belajar Matematika: Studi Pada Siswa SD/MI di Kota Makassar. Lentera Pendidikan: Jurnal Ilmu Tarbiyah Dan Keguruan, 19(1), 115.

https://doi.org/10.24252/lp.2016v1 9n1a1

Pradana, P. H. (2016). Pengaruh Pembelajaran Kooperatif Tipe NHT \& STAD Dan Motivasi Belajar Terhadap Hasil Belajar Matematika. Jurnal Gammath, I(2), 9-17.

Safaria, S. A., \& Sangila, M. S. (2018). Kemampuan Berpikir Kreatif Matematis Siswa SMP Negeri 9 Kendari Pada Materi Bangun Datar. Jurnal Al-Ta'dib, 11(2), 7390.
Sholihah, S. Z., \& Afriansyah, E. A. (2017). Analisis Kesulitan Siswa dalam Proses Pemecahan Masalah Geometri Berdasarkan Tahapan Berpikir Van Hiele. Mosharafa: Jurnal Pendidikan Matematika, 6(2), 287-298. https://doi.org/10.31980/mosharafa .v6i2.317

Solfitri, T., Siregar, H. M., \& Syari, R. (2019). The Analysis of Students ' Errors in Using Integration Techniques. Proceeding of the SS9 \& 3rd URICES, (2), 978-979.

Utami, A. S. (2017). Analisis kesalahan siswa dalam menyelesaikan soal cerita pokok bahasan komposisi fungsi di SMK Bakti Purwokerto. Alphamath, 3(2), 48-56.

Utami, N. W. (2011). Optimalisasi Sumber Belajar Dalam Peningkatan Apresiasi Siswa Terhadap Matematika. Seminar Nasional Dan Pendidikan Matematika: Matematika Dan Pendidikan Karakter Dalam Pembelajaran, 7, 366-375. Yogyakarta. 